\title{
Learning Partnership: Students and Faculty Learning Together to Facilitate Reflection and Higher Order Thinking in a Blended Course
}

\author{
Paige L. McDonald, Howard O. Straker, Karen S. Schlumpf, and Margaret M. Plack \\ The George Washington University \\ School of Medicine and Health Sciences
}

\begin{abstract}
This article discusses a learning partnership among faculty and students to influence reflective practice in a blended course. Faculty redesigned a traditional face-to-face (FTF) introductory physician assistant course into a blended course to promote increased reflection and higher order thinking. Early student reflective writing suggested a need for learner familiarization with levels of learning, types of reflection, and levels of reflective practice and for revision of writing prompts to encourage greater depth and breadth of reflection. This article presents results from an analysis of students' writings prior to and after the learning intervention and revision of writing prompts. Writings from Week 1 and Week 8 of the course were analyzed for level of reflective practice, depth and breadth of reflection, and depth of higher order thinking. Results indicate an increase in level, depth, and breadth of reflection post-intervention. Results also indicate an increase in occurrences in higher order thinking post-intervention. Findings suggest that purposive course design, combined with instruction on reflection and appropriate reflective prompts, can influence breadth and depth of reflection and higher order thinking in a blended course.
\end{abstract}

\section{Learning Partnership: Students and Faculty Learning Together to Facilitate Reflection and Higher Order Thinking in a Blended Course}

The increasing complexity of today's healthcare environment demands that practitioners integrate multiple streams of information in clinical decision making. To meet these demands, future practitioners must be prepared to think critically and integrate knowledge and experience in the resolution of complex problems. The reflective process has been shown to promote critical thinking and knowledge integration (Dunfee, Rindflesch, Driscoll, Hollman, \& Plack, 2008; Plack et al., 2007; Plack, Driscoll, Marquez, \& Greenberg, 2010; Plack \& Santasier, 2004). Recognizing reflection as the cognitive process that facilitates the integration of personal experience to clinical decision making and practice, health professions education has demonstrated increasing focus on developing reflective practitioners (Dannefer, 2013; Kinsella, 2009; Maree \& Van Rensburg, 2013). Reflection is considered a professional competency for physical therapists (Commission on Accreditation of Physical Therapy Education, 2014), nurse practitioners (National Organization of Nurse Practitioner Faculties, 2006), and physician assistants (National Commission on the Certification of Physician Assistants, 2012). Reflection can be used to foster clinical reasoning (de Swardt, du Toit, \& Botha, 2012; Plack \& Santasier, 2004; Mamede, van Gog, van den Berge, van Saase, \& Schmidt, 2014) and/or promote professionalism (Baerenstein, Oeschlager, Chang, \& Wenrich, 2009; Plack \& Santasier, 2004) in health professions education. In health professions 
curricula, clinical experiences often occur in the later phase of training, and at that point in the curriculum students are expected to be highly prepared to engage as professionals. Reflection is a skill that must be learned and like any other skill, requires practice. To ensure that students are adequately prepared to maximize their learning and refine their decision-making skills when they enter the clinical environment, the reflective process should be introduced early in the curriculum. The didactic phase of education should promote reflection upon active learning within the classroom and encourage students to anticipate how that learning might apply to future scenarios. Case-based, simulation, and other methods of activelearning problem solving can be used to facilitate reflection.

Adopting active-learning strategies, such as reflective practice, with students traditionally reliant upon teacher-centric models of instruction, however, can prove challenging. Active learning requires both students and teachers to reconsider their roles within the classroom. Faculty and students must share responsibility for the learning process (Baepler, Walker, \& Driessen, 2014). Yet students unaccustomed to active-learning processes and faculty reliant upon lecture-based instruction may require time and practice in order to develop new learning and facilitation habits. Adopting course structures allowing action, interaction, and reflection creates an environment conducive to higher order cognitive processes (Jensen, 1998) required for higher levels of learning (Illeris, 2003). Blended models of learning can promote the cycle of action, interaction, and reflection required to promote higher levels of learning (McDonald, 2012). Online journals can allow learners in a blended course to reflect upon classroom experiences (McDonald, Straker, \& Lyons, 2014). However, little research has been done on the efficacy of online journals in promoting reflection in the health sciences. This article presents one model of blending to promote reflective practice in a physician assistant (PA) course. Applying a mechanism of journal assessment developed by Plack, Driscoll, Blissett, McKenna, and Plack (2005), researchers questioned whether, and to what level, student online journals demonstrated reflection.

\section{Literature Review}

\section{Experiential Learning and the Reflective Process}

Reflection or reflective practice is an internal process of analyzing experience to build a new or deeper understanding or knowledge. It can entail cognitive and affective functions (Boud, Keogh, \& Walker, 1985). Professional education builds upon experience. Often in the later phase of education of health professionals, an apprenticeship model is used, and students are placed in the field to gain experience alongside working professionals. Schön (1983), a reflective theorist, was concerned with professional practice because it requires significant problem solving. He posited that when a professional confronts a unique or anomalous problem or situation, the solution requires new learning and often higher levels of thinking. Schön borrows heavily from experiential learning theory (Dewey, 1916, 1938) in his theory of reflective practice. Experiential learning proposes reflection as a mechanism allowing critical assessment of current problems in comparison to previous experiences to determine appropriate future action (Dewey, 1916, 1938; Kolb, 1984). Schön describes a dialogic relationship between reflection and action as essential to reflective practice, identifying two types of reflection: reflection-in-action and reflection-on-action. Developing these types of reflection enables practitioners to know how to respond skillfully to complex situations (Schön, 1983). In an educational setting, promoting reflection-in-action requires learning experiences that challenge students to compare a new or surprising situation to previous experiences and existing knowledge in problem solving. Facilitating reflection-on-action necessitates opportunities for students to question how new learning experiences contributed to or altered their understanding of concepts, assumptions, or premises by which they solved a problem (Schön, 1983). Killion and Todnem (1991) extend Schön's model to argue that future practitioners must also be able to use previous experiences and knowledge to anticipate consequences of future actions, or in other words, they must be able to reflect-for-action. Consequently, didactic coursework must be designed to allow opportunities for reflection prior to, during, and after a learning experience. Yet questions remain as to the process by which students reflect in each phase. 
While Schön focused on the timing of the reflective process in learning from experience, Mezirow (1991) focused more directly on the nature of the reflection that occurs. He describes the reflective process as critically questioning the content, process, and premise underlying an experience or problem to make meaning of it, or to come to a better understanding. In content reflection learners reconsider the "what" of experience, describing and analyzing the situation or problem from multiple perspectives to obtain a deeper understanding (p. 107). Process reflection requires learners to analyze the "how" of experience, or the processes or strategies involved, as well as looking at alternative processes or strategies used to understand the situation or solve problems (p. 108). Finally, premise reflection focuses learning on the "why" of experience and occurs when learners begin to recognize and critique their own biases, values, beliefs, and assumptions (p. 108). Often premise reflection also occurs when learners begin to examine the existence of problems that stem from unconscious bias. Premise reflection is the most challenging type of reflection to achieve. As a form of transformational learning that requires a higher order, conscious thought process (Plack \& Greenberg, 2005), reflection is the process by which individuals can correct assumptions, revise interpretations, and modify behaviors (Mezirow, 1991). It is also the process by which learners can assess gaps in their own knowledge or skill.

\section{Blended Learning Design to Foster Critical Reflection}

Blended learning promises to meet the increasing demands of health professions education. Blended learning studies reveal increased student participation in course activities (Geçer \& Dag, 2012), student perceptions of improved analytical skills (Chen \& Jones, 2007), increased sense of community and connectedness (Carter-Brown, 2009; Comey, 2009; Lotrecchiano, McDonald, Lyons, Long, \& Farber, 2013), increased ability to apply course concepts in the field (Chen \& Jones, 2007), and increased reflection upon action and future reflective practice (Cooner, 2010). In a meta-analysis of online learning studies, Means, Toyama, Murphy, Bakia, and Jones (2009) found that the addition of mechanisms for reflection added to increased learning outcomes in online and blended courses. Health sciences literature is beginning to present research on blended learning, particularly in relation to the nursing profession (Hsu, 2012; Stephens \& Hennefer, 2013). Blended learning studies are also beginning to appear in physical therapy (Bello-Haas, Proctor, \& Scudds, 2013), pharmacy (Ortega-Rivas, Saorín, de la Torre, \& Elsheikha, 2013), and medical education (Duque et al., 2013; Sanchez-Mendiola et al., 2013; Stewart, Inglis, Jardine, Koorts, \& Davies, 2013).

While there are many definitions of blended learning, faculty had specific pedagogical goals for course redesign, so we adopted a definition aligned with those goals. Picciano (2007) defines blended learning as the integration of online (OL) and traditional face-to-face (FTF) class activities "in a planned, pedagogically valuable manner" wherein a portion of FTF time is replaced by online activity (p. 10). The thoughtful integration of OL and FTF learning in a blended course can yield higher learning outcomes than either FTF or OL learning in isolation (Garrison \& Kanuka, 2004; Garrison \& Vaughan, 2008; McDonald, 2012). Students in blended courses have reported higher levels of learning than they have previously experienced in other modalities as a result of the purposive structuring of OL and FTF activities and interactions, which promote a cycles of reflection upon a topic, critical discussion of that topic, application of course concepts and further reflection upon application (McDonald, 2012).

\section{Journals as Mechanisms for Reflection}

Reflective writing has been shown to promote student reflection, particularly in health professions education (Plack et al., 2005; Plack et al., 2007; Wald, Borkan, Taylor, Anthony, \& Reis, 2012). In blended courses, OL journals can provide a mechanism to allow students to reflect-on-action after learning experiences. However, identifying a method for assessing levels of reflection in students' journals can prove challenging, particularly when the goal is to determine whether the course structure facilitated awareness and questioning of biases and assumptions, which can lead to higher levels of thinking, or premise reflection. Grounded in the reflective processes of both Mezirow and Schön, Plack et al. (2005) designed a tool to assess the breadth of reflective writing in physical therapy student journals. 
Educators commonly use Bloom's Taxonomy (1956) in developing objectives and assessing student learning and performance. This taxonomy can be used to differentiate between lower order and higher order thinking. Bloom defined six levels of thinking in the cognitive domain (from lowest to highest): knowledge, comprehension, application, analysis, synthesis, and evaluation. Plack et al. (2007) refined and applied this taxonomy to assess the depth of higher order thinking in the reflective writing of medical students.

\section{Course Design}

In 2013, faculty redesigned an introductory physician assistant course from a fully FTF course to a blended course. Health, Justice, and Society (HJS) introduces students to the social determinants of health while also asking them to consider controversial issues, such as bias and ethical dilemmas influencing the decision-making of future practitioners. One of the pedagogical goals in course redesign is to create a structure supportive of critical thinking and reflective practice among our PA students. Faculty integrated OL and FTF activities to allow students to experience reflection-for-action, reflection-inaction, and reflection-on-action (Killion \& Todnem, 1991; Schön, 1983). OL activities and interactions have been shown to support reflection on course concepts (McDonald, 2012). OL activities in this course included readings, lectures, discussions, or quizzes prior to FTF class sessions to allow students to reflect upon course concepts prior to applying them in our FTF class sessions. FTF class sessions were then reserved for application of concepts in simulated "real-world" scenarios, such as standardized patients and case-based projects, promoting reflection-in-action among smaller groups of students and among students and instructors. Debriefs following these scenarios promoted reflection-on-action and reflection-foraction. Required online journal entries also promoted further reflection-on-action and reflection-foraction.

In addition to facilitating reflection, faculty designed this blended course to achieve the following objectives: (1) students will reflect on course concepts prior to FTF class sessions to promote awareness of their own biases, beliefs, and assumptions prior to applying concepts to real-world scenarios in FTF settings; (2) journal writing will enable students to become more aware of how they might apply the concepts discussed in their future practice, which is particularly important given that the students will not begin clinical rotations until their second year in the program; (3) the OL journal format will enable students to maintain their journals and perhaps use them once they are in the clinical settings; and (4) students will adopt a formal mode of reflection (such as journaling) as a part of their future clinical practice. Table 1 provides an overview of a week of assignments within the course modeling this adopted structure. It should be noted that journal entries were required only four times during the semester, though students were encouraged to journal as often as they felt necessary.

Table 1 Course Overview

\begin{tabular}{|c|c|c|c|c|c|c|}
\hline Monday & Tuesday & Wednesday & Thursday & Friday & Saturday & Sunday \\
\hline $\begin{array}{l}\text { Readings } \\
\text { and } \\
\text { Lectures }\end{array}$ & $\begin{array}{l}\text { Online } \\
\text { Discussio } \\
\text { n/Online } \\
\text { Activity/ } \\
\text { Online } \\
\text { Quiz } \\
\text { (Reflect) }\end{array}$ & $\begin{array}{l}\text { Online } \\
\text { Discussion/ } \\
\text { Online } \\
\text { Activity/ } \\
\text { Online Quiz } \\
\\
\text { (Reflect) }\end{array}$ & $\begin{array}{l}\text { Online } \\
\text { Summary }\end{array}$ & $\begin{array}{l}\text { FTF Class } \\
\\
\text { (Reflect- } \\
\text { in-action } \\
\text { and } \\
\text { reflect-on- } \\
\text { action) }\end{array}$ & & $\begin{array}{l}\text { Journal Entry } \\
\text { (if required) } \\
\text { (Reflect- } \\
\text { in-action } \\
\text { and } \\
\text { reflect-on- } \\
\text { action) }\end{array}$ \\
\hline
\end{tabular}


In the first FTF class session, faculty recognized that course structure alone was not sufficient to facilitate the types and levels of reflection required of future practitioners. On the first day of the course, faculty asked students to reflect on how they thought an assigned reading might relate to the course and to their future practice. The following were questions provided to students:

- What stood out for you from the assigned reading?

- What made that content stand out for you?

- Why might we have assigned the particular reading for today?

- How might this book relate to our course?

In reviewing student responses to these questions and early journal entries, faculty noted students simply provided a description of their reading and did not go further to reflect upon or think critically about what they were learning through their readings or how they might relate to their future practice. Faculty questioned whether students needed further instruction in the purpose of the reflective process and the types and levels of reflection they should be striving to achieve in future assignments. As a result, in a subsequent FTF class session, faculty provided students an introduction to higher order thinking using and updated model of Bloom's Taxonomy (1956) of learning domains as depicted in Figure 1.

Figure 1. Depiction of Bloom's Taxonomy (1956).

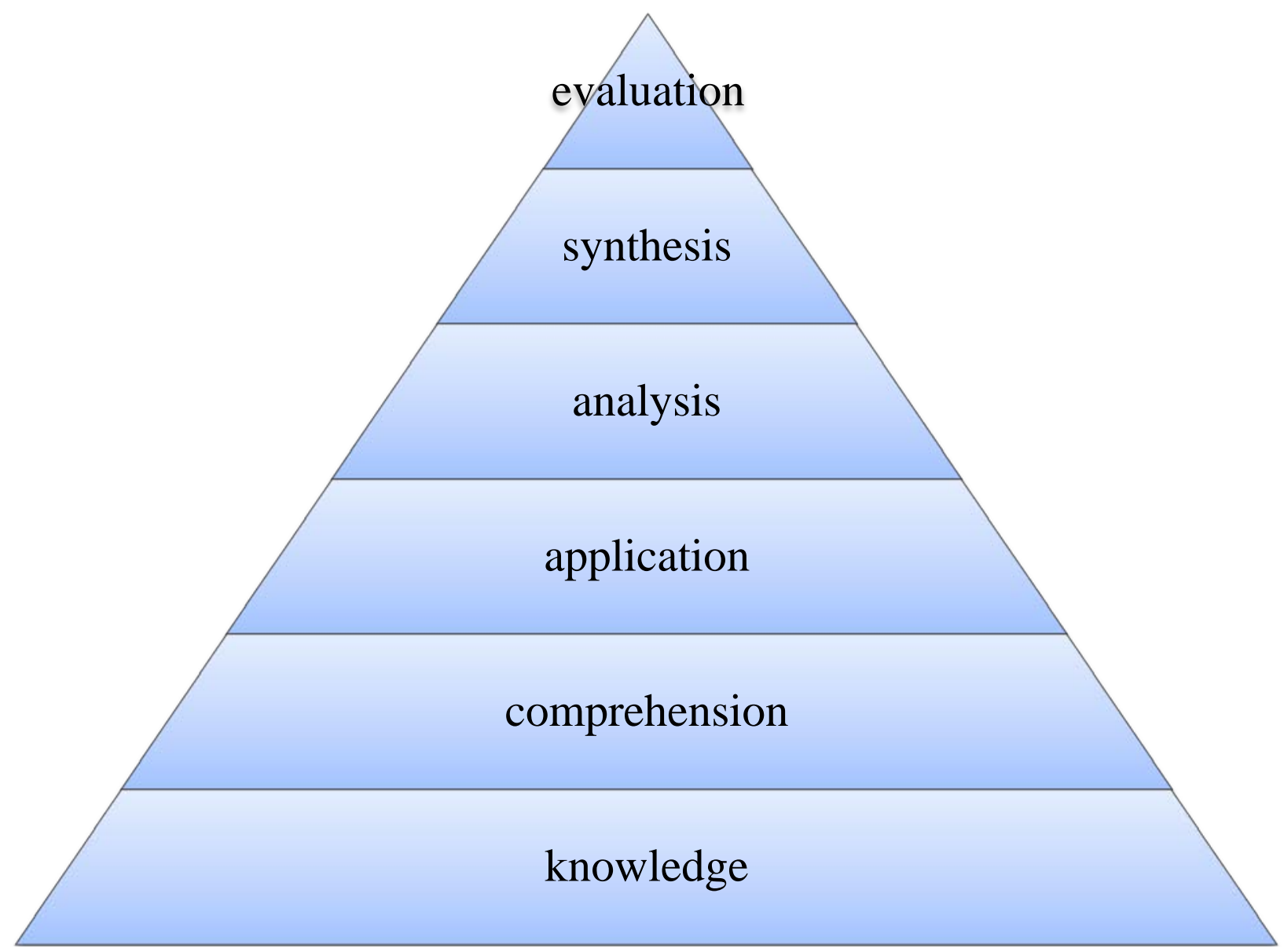


Students were asked to consider course objectives and determine the anticipated levels of learning outcomes in the HJS course. Many students readily recognized the expectation in this course was that the learner would at least achieve the application level of knowledge; few acknowledged that to be prepared for future practice, they would need to achieve higher levels of cognitive processing, including evaluation and creation of knowledge. Using Figures 1 and 2, faculty then explained that the intentional use of cycles of reflection in the course was designed to engage students in the higher order thinking required for future clinical practice (Bloom, 1956; Killion \& Todnem, 1991; Schön, 1983).

Figure 2. Types of reflection (Killion \& Todnem, 1991; Schön, 1983).

\section{In-Action}

\section{On-Action}

\section{For-Action}

- Occurs in the midst of activity

- In the moment examination

- Evaluation of past experience

- Examination of thoughts, feelings, outcomes

- Preparatory examination prior to activity

- Alternative solutions

In addition to the types of reflection and the concept of higher order thinking, faculty discussed the levels of reflective practice described by Mezirow in 1991 (see Figure 3). Faculty explained how reflective practice enables practitioners to apply existing knowledge to determine potential solutions to new problems while simultaneously creating new knowledge. However, to be most effective, students must move beyond description of experience and the processes or strategies used in solving problems to consider the assumptions, values, and beliefs underlying their decision-making processes.

Figure 3. Mezirow's (1991) levels of reflective practice.

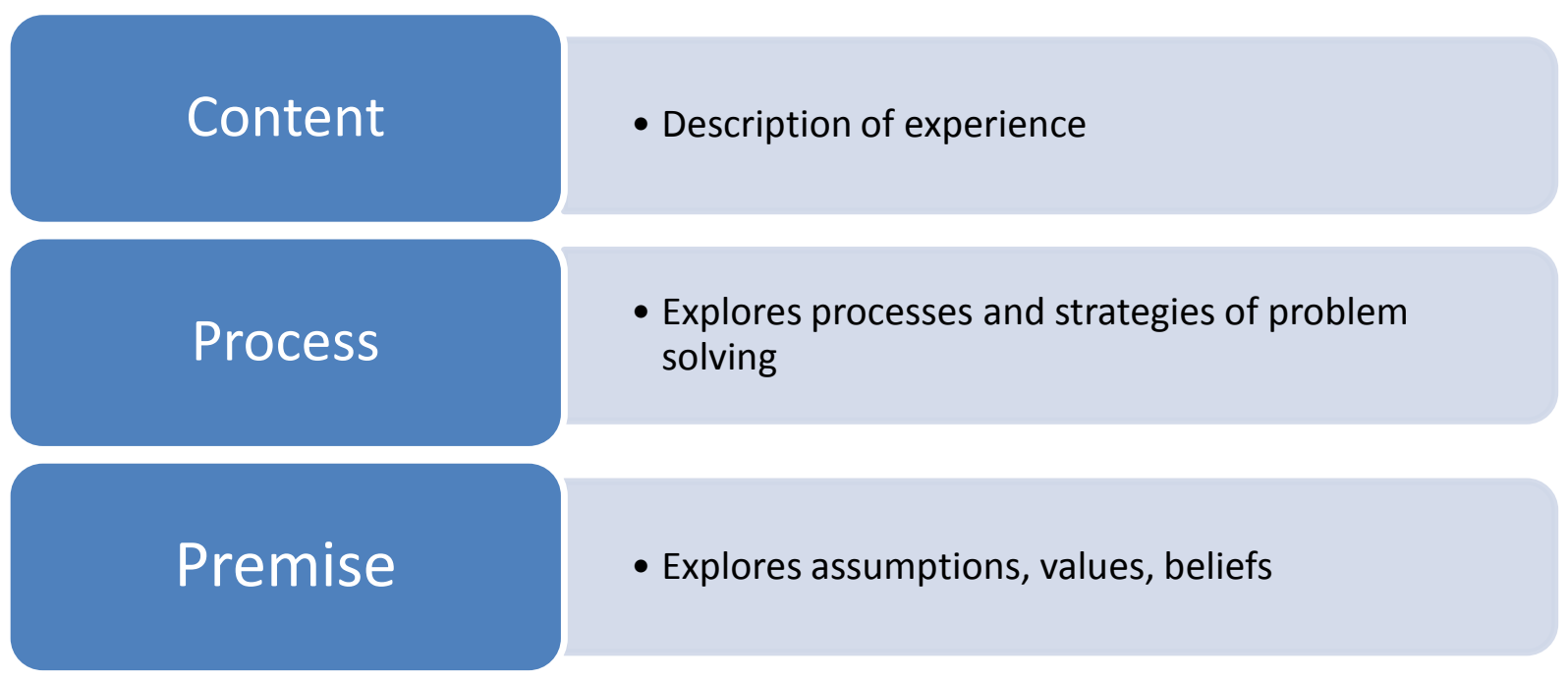


Through the reflective process, faculty also recognized how a partnership between student and instructor can develop in the classroom. As they guided students through the different types and levels of reflection, faculty also evaluated the types of questions they were using to prompt depth of thinking and breadth of reflective processing in students. Just as reflection is a skill that must be honed, asking effective questions to prompt deeper thinking and reflective processing is a skill that requires ongoing refinement. While students worked on their reflective skills, faculty worked on their reflective questioning skills. As a result, the following reflective questions were posed to students in their Week 8 journal assignment in which they were asked to respond to one or more of the prompts below:

- Describe a point in the course in which you were most engaged/disengaged in learning and why you think you felt this way. Include your thoughts and feeling at that time.

- Discuss what you learned about yourself: areas of personal strengths, where you need improvement, areas in which you had difficulty, where you felt particularly good about your values, beliefs, etc. Explain.

- Discuss a time when you were working with your classmates (or standardized patient) that made you stop and think, "Wow! That was not what I expected!” What did it make you think? How did it make you feel? What did you do? What did you learn from the experience? Elaborate.

- What has been your greatest challenge so far? Were you able to overcome that challenge? If so, how? If not, why and what would have helped? What did you learn from this challenge? What will you change in the future?

- Describe something you learned that you did not expect to learn or that you had not thought about before. How did you learn that? How might this impact your development as a PA?

\section{Methods}

Physician assistant students enrolled in the HJS course $(n=66)$ during summer 2014 completed various writing assignments as a requirement of the course. The students consisted of 50 females and 16 males. As noted, on the first day of the course, students responded in writing to a series of discussion questions. Again in Week 8, students responded to a series of reflective questions posed by faculty using an online platform.

Three methods of assessment were used to analyze student writing. These methods were drawn from the previous work of one of the authors and are rooted in Mezirow's (Plack et al., 2005; Plack et al., 2007) reflective process and Bloom's Taxonomy of higher order thinking (Plack et al., 2007; Dunfee et al., 2008). Consistent with previous methods, two levels of analysis were performed: (1) the elements of reflection and depth of higher order thinking (content, process, premise, Level I, Level II, Level III) were assessed at the level of the words, sentences, and paragraphs within each written submission, and (2) the overall depth of reflection (no evidence of reflection, evidence of reflection, evidence of critical reflection) of the student's writing was assessed at the level of the written submission (see Table 2).

All submissions were collected or downloaded from Blackboard, matched (i.e., same student submissions for Week 1 and Week 8), and to maintain anonymity and confidentiality were de-identified and assigned a random number by one of the researchers not involved in the analysis. Student writing from Week $1(n=62)$ and Week $8(n=66)$ of a blended PA course was analyzed for evidence of the elements of reflection (content, process, premise) and higher order thinking (Level I, II, III) to determine the extent to which students demonstrated depth and breadth of reflection (see Table 1). To determine the extent to which the students' OL journals demonstrated a progression toward higher levels of reflection as the course progressed, the raters assessed each submission from Week 1 and Week 8 as showing no evidence of reflection, showing evidence of reflection, or showing evidence of critical reflection. Only matched submissions were included in this analysis $(n=61)$. Descriptive statistics were used to quantify the types of reflection and level(s) of higher order processing evident in each submission as well as the highest level of reflective thinking evident in each submission. 
Table 2 Rating Checklist for Reflective Journals

\begin{tabular}{|c|c|c|c|c|c|}
\hline & & & Brief definition & Presence & Comments \\
\hline Analysis I & Code & $\begin{array}{l}\text { Element of } \\
\text { reflection }\end{array}$ & $\begin{array}{l}\text { Unit of analysis: Words, sentences, and } \\
\text { paragraphs }\end{array}$ & & \\
\hline \multirow[t]{3}{*}{ Breadth } & $\mathrm{CON}$ & Content & $\begin{array}{l}\text { The student attempts to explore the } \\
\text { problem/experience to better understand it. } \\
\text { The student goes beyond just describing an } \\
\text { event to exploring the problem or situation. } \\
\text { The student may begin to view the } \\
\text { problem/experience from different } \\
\text { perspectives. }\end{array}$ & & \\
\hline & $\begin{array}{l}\text { PRO } \\
\text { C }\end{array}$ & Process & $\begin{array}{l}\text { The student begins to describe the strategies } \\
\text { and/or processes involved in an experience. } \\
\text { These may include strategies/processes used } \\
\text { in learning, problem solving, or managing a } \\
\text { situation. The student may begin to explore } \\
\text { other strategies available for use. }\end{array}$ & & \\
\hline & $\begin{array}{l}\text { PRE } \\
\text { M }\end{array}$ & Premise & $\begin{array}{l}\text { The student recognizes and begins to explore } \\
\text { or critique his or her own assumptions, values, } \\
\text { beliefs, and biases. The student may begin to } \\
\text { seek multiple perspectives and alternative } \\
\text { explanations. }\end{array}$ & & \\
\hline \multirow[t]{2}{*}{ Depth } & I & $\begin{array}{l}\text { Knowledge } \\
\text { / } \\
\text { comprehen } \\
\text { sion }\end{array}$ & $\begin{array}{l}\text { The student describes the experience/content } \\
\text { for the purpose of understanding or making } \\
\text { meaning; he or she might explain what } \\
\text { happened from his or her perspective; might } \\
\text { describe his or her thoughts, feelings, actions; } \\
\text { might state the results of his or her actions }\end{array}$ & & \\
\hline & II & Analysis & $\begin{array}{l}\text { The student attempts to deconstruct the } \\
\text { experience; analyzes what happens from his } \\
\text { or her perspective; differentiates between } \\
\text { perceptions, feelings, thoughts, facts, etc.; } \\
\text { begins to examine alternative explanations; he } \\
\text { or she begins to explore something about the } \\
\text { experience that stands out as interesting, } \\
\text { different, confusing, unique; he or she begins } \\
\text { to raise questions; he or she begins to explore } \\
\text { why this particular experience stands out for } \\
\text { him or her. The more skillful reflector would } \\
\text { analyze the experience from a number of } \\
\text { different perspectives beyond the self. }\end{array}$ & & \\
\hline
\end{tabular}




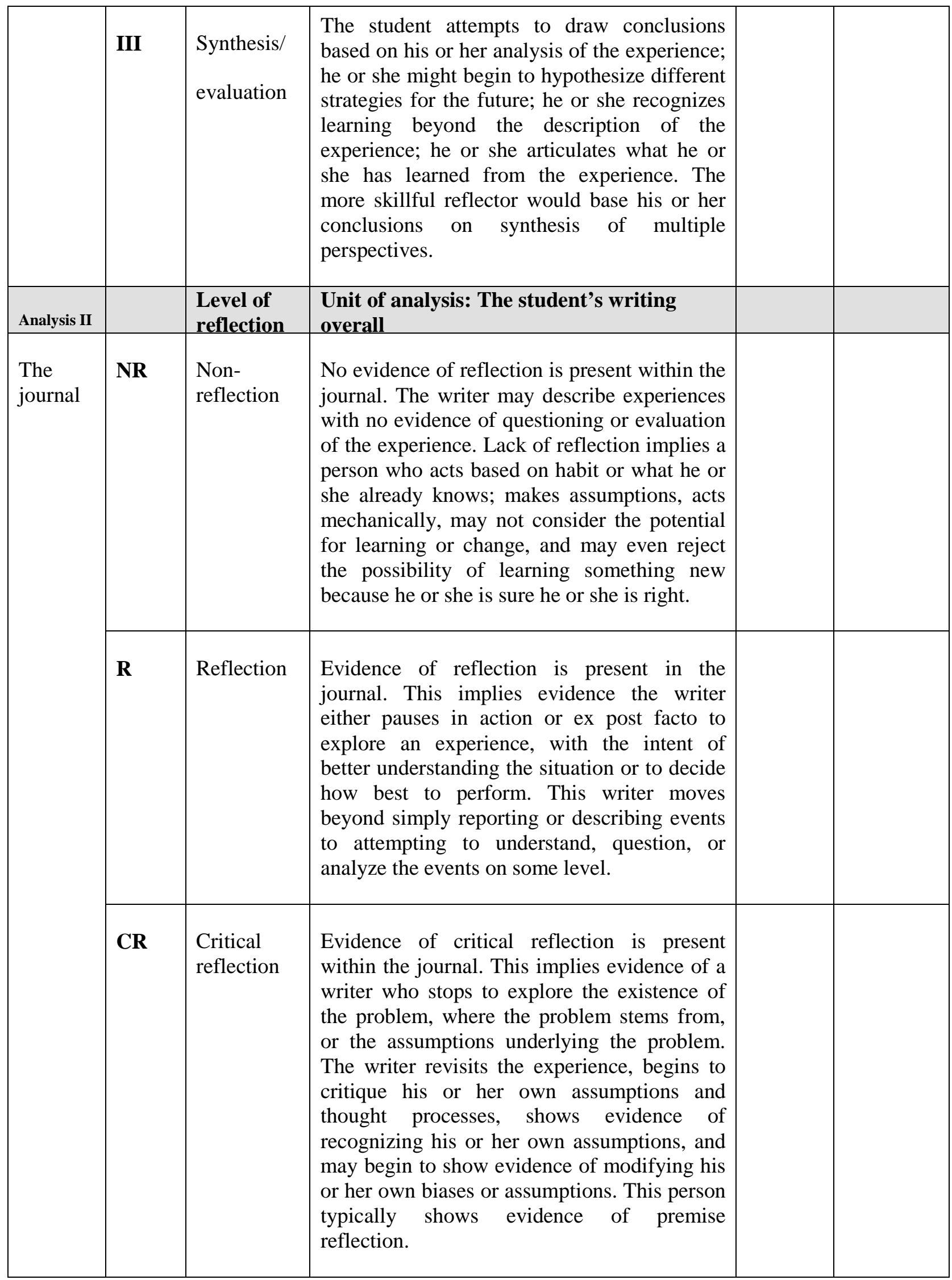


To optimize objectivity in the analysis of the journal submissions, two researchers independently rated each written submission. The two researchers then shared their ratings for each submission. Any discrepancies were discussed, and consensus was developed.

The Office of Human Subjects Research Institutional Review Board at The George Washington University deemed this project exempt.

\section{Results}

Sixty-two submissions from Week 1 and 66 submissions for Week 8 were coded for evidence of reflection. See Appendix A for exemplar quotes from student journals providing evidence of each of the elements of reflection. After coding, essays were matched on subject ID to compare the evidence of reflection between Week 1 and Week 8 submissions. One journal submission from Week 8 was not legible, and four essays from Week 8 did not have a corresponding Week 1 submission. As a result, these five submissions were excluded from this analysis.

Table 3 Evidence of the Elements of Reflection and Higher Order Thinking in Student Writing

\begin{tabular}{|c|c|c|c|c|c|}
\hline Analysis I & & $\begin{array}{l}\text { Elements of reflection } \\
\text { and higher order } \\
\text { thinking }\end{array}$ & $\begin{array}{ll}\text { Week } & 1 * \\
n(\%) & \end{array}$ & $\begin{array}{ll}\text { Week } & 8^{*} \\
n(\%) & \end{array}$ & $\begin{array}{l}\text { Number of } \\
\text { new } \\
\text { occurrences }\end{array}$ \\
\hline \multirow[t]{6}{*}{$\begin{array}{l}\text { Unit of analysis: } \\
\text { Words, } \\
\text { sentences, and } \\
\text { paragraphs }\end{array}$} & Breadth & Content & $\begin{array}{l}22 \\
(36.1 \%)\end{array}$ & $52(85.2 \%)$ & 31 \\
\hline & & Process & $\begin{array}{l}11 \\
(18.0 \%)\end{array}$ & $46(75.4 \%)$ & 35 \\
\hline & & Premise & $\begin{array}{c}3 \\
(9.9 \%)\end{array}$ & 19 (31.1\%) & 18 \\
\hline & Depth & $\begin{array}{l}\text { Level I: } \\
\text { Knowledge/comprehensi } \\
\text { on }\end{array}$ & $\begin{array}{l}56 \\
(91.8 \%)\end{array}$ & 60 (98.4\%) & 5 \\
\hline & & Level II: Analysis & $\begin{array}{l}26 \\
(42.6 \%)\end{array}$ & $55(90.2 \%)$ & 30 \\
\hline & & $\begin{array}{l}\text { Level III: } \\
\text { Synthesis/evaluation }\end{array}$ & $\begin{array}{l}15 \\
(24.6 \%)\end{array}$ & $40(65.6 \%)$ & 28 \\
\hline
\end{tabular}

*Percentages do not add up to $100 \%$ because each submission may have shown evidence of some or all of the elements of reflection and higher order thinking.

Across all six elements of breadth of reflection and depth of higher ordered thinking, researchers found an increased number of occurrences of reflection and higher order thinking from Week 1 to Week 8 elements of reflection and higher order thinking.

Thirty-one new occurrences of content reflection were observed in Week 8 as compared to Week 1. Process reflection had the largest increase, with 35 new occurrences for a total of 46 out of 61 students demonstrating evidence of process reflection in Week 8. During the first week, three submissions illustrated premise reflection, the most challenging type of reflection, while 18 new occurrences were identified in Week 8 submissions. Of note, two students who showed evidence of content and premise reflection in Week 1 did not show evidence of these elements of reflection in their Week 8 submissions.

Over $90 \%$ of the submissions for the Week 1 showed evidence of knowledge and comprehension, the first level of higher order thinking. Five students who did not show evidence of Level I reflection in 
Week 1 did show evidence in Week 8. In addition, 30 new occurrences of Level II reflection were observed in Week 8 as compared to Week 1. Over 65\% of the Week 8 submissions showed evidence of the highest level of higher order thinking (Level II), an increase of 28 occurrences of synthesis/evaluation. Three students exhibited evidence of synthesis and evaluation (Level III) in their Week 1 submissions but did not show evidence of higher order thinking in Week 8. Additionally, one of the Week 1 student journals showed evidence of the first two levels of learning but did not illustrate comprehension or analysis in the Week 8 submission.

In examining the three levels of reflection (see Table 4), results indicated an overall increase in reflection, with the number of submissions showing no evidence of reflection decreasing and the number of submissions showing both reflection and critical reflection increasing.

Table 4 Level of Reflection Achieved in Student Writing

\begin{tabular}{|l|l|l|l|}
\hline Analysis II & Level of reflection & $\begin{array}{l}\text { Week } \\
(\boldsymbol{n}=\mathbf{6 1})\end{array}$ & $\begin{array}{l}\text { Week } \\
(\boldsymbol{n}=\mathbf{6 1})\end{array}$ \\
\hline Unit of analysis: The journal submission & Non-reflection & $37(60.6 \%)$ & $8(13.1 \%)$ \\
\hline & Reflection & $22(36.1 \%)$ & $36(59.0 \%)$ \\
\hline & Critical reflection & $2(3.3 \%)$ & $17(27.9 \%)$ \\
\hline
\end{tabular}

While almost $40 \%$ of the Week 1 journals showed evidence of reflection or critical reflection, this number more than doubled, with over $85 \%$ of the students demonstrating reflection or critical reflection in their Week 8 submissions. Fourteen students stayed at the reflection level from Week 1 to Week 8; one student achieved critical reflection both weeks (results not shown). Over 62\% (38 out of 61 students) moved up one or two levels in reflection between Weeks 1 and Week 8. Twenty-two students progressed from nonreflective submissions to reflective submissions, and six students advanced from reflective to critically reflective submissions. Ten students advanced from nonreflective submissions in Week 1 to critically reflective reflections in Week 8 (results not shown). Conversely, two students' writing showed a shift from reflective to nonreflective writing, and one student moved from submitting a critically reflective journal entry in the first week to a nonreflective journal entry in the eighth week.

\section{Discussion}

Results of the journal analyses provide evidence that a blended-learning course format in conjunction with instruction on types and levels of reflection can promote reflective thinking. The number of nonreflective journal submissions was 4.5 times smaller, while the number of critically reflective journal submissions was 8.5 times larger from Week 1 to Week 8 . The assessment of the elements within each of the journal submissions demonstrates both a substantial increase in depth and breadth of reflections over this period. Content and process elements were present in at least three-fourths of the student's journals in Week 8, while elements of premise reflection increased by almost one third. It is not surprising that evidence of premise reflection, although markedly increased (31.1\%), did not increase to the extent that process or content reflection did because premise reflection is the more difficult type of reflection to achieve, particularly when reflecting independently (Mezirow, 1991). Still there was over a fivefold increase in the number of journals with elements of premise reflection at Week 8 as compared to those of Week 1. It is often challenging for individuals to recognize their own assumptions; however, in this case, small-group FTF discussions in class in conjunction with personal reflective writing helped facilitate recognition of personal biases, values, and assumptions. These results are consistent with previous findings that blended learning can support reflection-on-action (Cooner, 2010; Means et al., 2009) and that reflective activities in OL and blended courses can lead to improved learning outcomes (Means et al., 2009).

Several factors may have contributed to the increases in reflection and higher order thinking noted in student submissions. The course was structured to facilitate cycles of reflection and discussion. 
FTF discussions augmented by OL journal reflections helped create various learning spaces in which students could engage in the reflective process. Journal writing occurred in close proximity to the activities students reflected on but after a collective FTF debriefing. This practice is consistent with the literature demonstrating how reflective writing can promote student reflection in health professions education (Plack et al., 2005; Plack et al., 2007; Wald et al., 2012) and that an online journals can serve as a mechanism for learners to reflect on classroom experiences in blended courses (McDonald, et al., 2014). Results also confirm that reflective practice can lead to higher levels of learning (Dunfee et al., 2008; Plack et al., 2007; Plack et al., 2010; Plack \& Santasier, 2004).

Further, peer discussions enabled students to share their personal values and beliefs, which may have influenced the degree to which students recognized their own biases, as evidenced by this exemplar quote from a student journal:

I mentioned that my most obvious subconscious bias as both a person and a provider may be against extremely religious people, as I tend to associate certain belief systems (ex: creationism, anti-vaccine) with a lack of education rather than with faith. I stated that I just couldn't understand how someone could believe in creationism, especially if they're involved in the sciences. A classmate (and my personal best friend) then perked up and stated that she, indeed, believed simultaneously in creationism and evolution. The conversation completely threw me off, because I was under the impression that those two belief systems were mutually exclusive.... I was very taken aback by the conversation, but it made me realize my assumptions are often completely incorrect.

The process of peer discussion followed by reflective journaling enabled students to recognize and write about their own biases and assumptions. These results confirm that blended courses can promote a process of action, interaction, and reflection leading to higher levels of learning (McDonald, 2012).

In addition, faculty introduced the levels and types of reflection as a guiding framework for students to use as they moved through the reflective process in their writing, providing them with a target they should be striving to achieve in their reflections. Having a framework of reflective questions students can pose to themselves when preparing their online submissions may have influenced the degree to which they achieved both a depth and breadth of thinking. Finally, as students honed their reflective skills throughout this blended class, faculty also reflected-in-action on their own teaching skills and worked to hone their questions to facilitate deeper and broader thinking. Guldberg and Pilkington (2007) have found that the types of questions researchers pose impact the outcome of online reflections. So it is possible that both students and faculty learned to pose a breadth of reflective questions that ultimately enhanced their thinking, which confirms the shared responsibility for reflective practice as an active learning strategy (Baepler, Walker, \& Dreissen, 2014).

Many factors may have contributed to the changes noted between Week 1 and Week 8 submissions. This was an exploratory study, and as a result no conclusions can be drawn as to causality. After reviewing the Week 1 submissions, faculty recognized the students' need for further instruction on the levels and types of reflection, along with their own need to refine the reflective questions they posed. Therefore, the reflective questions posed in Week 1 were not designed as a preassessment of students' ability to engage in reflection, which limits researchers' ability to infer degree of change based on the designed intervention. Future research should incorporate a preassessment of ability aligned with the types and levels of reflection prior to intervention. Also, future research is needed to assess the degree to which each of the potential contributing factors, including blended course structure, components of course design (OL journal submissions, FTF discussions, etc.), course content on the elements of reflection and higher order thinking, and types of reflective questions, contributed to changes noted in types and levels of reflection and higher order thinking achieved by individual students. In addition, while changes in types and levels of reflection were noted after eight weeks, longitudinal studies are needed to determine whether students achieved a habit of reflective practice in subsequent didactic courses and clinical practice. Finally, while changes were noted in the didactic setting, it would be important to evaluate the impact of reflective practice on clinical outcomes. 


\section{Conclusions}

Reflection is a skill that must be practiced and honed. In this blended learning classroom, facilitating the reflective process became a true partnership between students and instructors. As instructors reflected on their own practice, they learned to ask more refined reflective questions. As students learned about the reflective process and shared their values and beliefs about various components of the course, they too learned to refine their skills in reflection and higher order thinking. Several factors may have influenced the increase in reflection noted in student writing, including the blended course format with FTF peer discussions and online personal journaling, the provision of explicit instruction on reflective frameworks, and the skillful use of reflective questions.

\section{References}

Baepler, P., Walker, J. D., \& Driessen, M. (2014). It's not about seat time: Blending, flipping, and efficiency in active learning classrooms. Computers \& Education, 78, 227-236.

Baerenstein, A., Oelschlager, A. M., Chang, T. A., \& Wenrich, M. D. (2009). Learning professionalism: Perspectives of preclinical medical students. Academic Medicine, 84(5), 574-581.

Bello-Haas, V., Proctor, P., \& Scudds, R. (2013). Comparison of knowledge and knowledge application confidence in physical therapist students completing a traditional versus blended learning professional issues course. Journal of Physical Therapy Education, 27(1), 10-19.

Bloom B. S. (1956). Taxonomy of educational objectives Book 1: Cognitive domain. New York: Longman.

Boud, D., Keogh, R., \& Walker, D. (1985). Reflection: Turning experience into learning. New York: Kogan Page/Nichols Publishing.

Carter-Brown, C. B. (2009). Building communities: The effects of offering face-to-face meetings to students studying at a distance (Doctoral dissertation). ProQuest Dissertations and Theses, Retrieved from http://search.proquest.com.proxygw.wrlc.org/docview/992950856?accountid=11243. (992950856).

Chen, C., \& Jones, T. (2007). Blended learning vs. traditional classroom settings: Assessing effectiveness and student perceptions in an MBA accounting course. The Journal of Educators Online, 4(1), 115. Retrieved from (continued on next page) http://search.ebscohost.com.proxygw.wrlc.org/login.aspx?direct=true\&db=eric\&AN=EJ907743\& $\underline{\text { site }=\text { ehost-live }}$

Comey, W. (2009). Blended learning and the classroom environment: A comparative analysis of students' perception of the classroom environment across community college courses taught in traditional face-to-face, online and blended methods. (Doctoral dissertation). Retrieved from http://search.proquest.com.proxygw.wrlc.org/pqdtft/docview/288045934/F5BED03F694041F4P

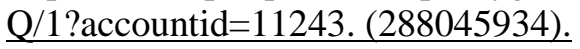

Commission on Accreditation of Physical Therapy Education (2014). CAPTE Accreditation Handbook. Retrieved from http://www.capteonline.org/AccreditationHandbook/ 
Cooner, T. S. (2010). Creating opportunities for students in large cohorts to reflect in and on practice: Lessons learnt from a formative evaluation of students' experiences of a technology-enhanced blended learning design. British Journal of Educational Technology, 41(2), 271-286.

Dannefer, E. F. (2013). Beyond assessment of learning toward assessment for learning: Educating tomorrow’s physicians. Medical Teacher, 35, 560-563. doi: 10.3109/0142159x

de Swardt, H. C., du Toit, H. S., \& Botha, A. (2012). Guided reflection as a tool to deal with the theorypractice gap in critical care nursing students. Health SA Gesondheid, 17(1), 1-9. doi:10.4102/hsag.v17i1.591

Dewey, J. (1916). Democracy and education: An introduction to philosophy of education. New York: Macmillan.

Dewey, J. (1938). Experience and education. New York: Kappa Delta Pi.

Dunfee, H., Rindflesch, A., Driscoll, M., Hollman, J., \& Plack, M. M. (2008). Assessing reflection and higher order thinking in electronic discussion threads in the clinical setting. Journal of Physical Therapy Education, 22(2), 60-66.

Duque, G., Demontiero, O., Whereat, S., Gunawardene, P., Leung, O., Webster, P., . . . Sharma, A. (2013). Evaluation of a blended learning model in geriatric medicine: A successful learning experience for medical students. Australasian Journal on Ageing, 32(2), 103-109. doi:10.1111/j.1741-6612.2012.00620.x

Garrison, D. R., \& Kanuka, H. (2004). Blended learning: Uncovering its transformative potential in higher education. The Internet and Higher Education, 7, 95-105.

Garrison, D., \& Vaughan, N. (2008). Blended learning in higher education. San Francisco, CA: John Wiley \& Sons.

Geçer, A., \& Dag, F. (2012). A blended learning experience. Educational Sciences: Theory and Practice 12(1), 438-442. Retrieved from http://akademikpersonel.kocaeli.edu.tr/akolburan/sci/akolburan18.10.2012_01.58.04sci.pdf

Guldberg, K., \& Pilkington, R. (2007). Tutor roles in facilitating reflection on practice through online discussion. Educational Technology \& Society, 10(1), 61-72.

Hsu, L. L. (2012). Qualitative assessment of a blended learning intervention in an undergraduate nursing course. Journal of Nursing Research, 20(4), 291-298. doi:10.1097/jnr.0b013e31827363bc

Illeris, K. (2003). Towards a contemporary and comprehensive theory of learning. International Journal of Lifelong Education, 22(4), 396-406.

Jensen, E. (1998). Introduction to brain-compatible learning. San Diego, CA: Brain Store.

Killion, J., \& Todnem ,G. (1991). A process for personal theory building. Educational Leadership, 48(6), $14-16$.

Kinsella, E. A. (2009). Professional knowledge and the epistemology of reflective practice. Nursing Philosophy, 11, 3-14. 
Kolb, D. A. (1984). Experiential learning: Experience as a source of learning and development. Englewood Cliffs, NJ: Prentice Hall.

Lotrecchiano, G. R., McDonald, P. L., Lyons, L., Long, T., \& Farber M. (2013, Jan.). Blended learning: Strengths, challenges, and lessons learned in an interprofessional training program. Maternal and Child Health Journal, 17(9), 1725-1734.

Mamede, S., van Gog, T., van den Berge, K., van Saase, J. L. C. M., \& Schmidt, H. G. (2014). Why do doctors make mistakes? A study of the role of salient distracting clinical features. Academic Medicine, 89(1), 114-120. doi:10.1097/ACM.0000000000000077

Maree, C., \& Van Rensburg, G. H. (2013, September). Reflective learning in higher education: Application to clinical nursing. African Journal for Physical, Health Education, Recreation and Dance, (Supplement 1), 44-45.

McDonald, P. L. (2012). Adult learners and blended learning: A phenomenographic study of variation in adult learners' experiences of blended learning in higher education. (Doctoral dissertation). ProQuest Dissertations and Theses, (992950856)

McDonald, P. L., Straker, H. O., \& Lyons, L. B. (2014). Blending for sustainability: Aligning the needs of adult learners and the needs of health sciences education. In J. K. Holtz, S. B. Springer, \& C. Boden-McGrill (Eds.), Building sustainable futures for adult learners. Charlotte, NC: Information Age Publishing.

Means, B., Toyama, Y., Murphy, R., Bakia, M., \& Jones, K. (2009). Evaluation of evidence based practices in online learning: A meta-analysis and review of online learning studies. Washington, DC: U.S. Department of Education. Retrieved from Department of Education website: http://www2.ed.gov/rschstat/eval/tech/evidence-based-practices/finalreport.pdf

Mezirow, J. (1991). Transformative dimensions of adult learning. San Francisco: Jossey-Bass.

National Commission on the Certification of Physician Assistants (2012). Competencies for the physician assistant profession. Retrieved from https://www.nccpa.net/Upload/PDFs/Definition\%20of\%20PA\%20Competencies.pdf

National Organization of Nurse Practitioner Faculties (2006). Domains and competencies of nurse practitioner practices March 2006. Retrieved from www.nonpf.org/?page=14

Ortega-Rivas, A., Saorín, J. L., de la Torre, J., \& Elsheikha. H. (2013). Touch-pad mobile devices for blended learning in immunology practicals. Medical Education, 47(5), 518-519.

Picciano, A. G. (2007). Introduction. In A. G. Picciano \& C. D. Dzuiban (Eds.), Blended learning research perspectives (pp. 5-17). Needham, MA: The Sloan Consortium.

Plack, M. M., Driscoll, M., Blissett, S., McKenna, R. M., \& Plack, T. P. (2005). A method for assessing reflective journal writing. Journal of Allied Health, 34(4), 199-208.

Plack, M. M., Driscoll, M., Cuppernull, L., Marquez, M., Maring, J., \& Greenberg, L. (2007). Assessing reflective writing on a pediatric clerkship by using a modified Bloom's Taxonomy. Ambulatory Pediatrics, 7, 285-291. 
Plack, M. M., Driscoll, M., Marquez, M., \& Greenberg, L. (2010). Peer-facilitated virtual action learning: Facilitating reflection and identifying challenges on a pediatric clerkship. Academic Pediatrics, 85, 706-709.

Plack, M. M., \& Santasier, A. (2010). Reflective practice: A model for facilitating critical thinking skills within an integrative case study classroom experience. Journal of Physical Therapy Education, 18(1), 4-12.

Sánchez-Mendiola, M., Martínez-Franco, A., Rosales-Vega, A., Villamar-Chulin, J., Gatica-Lara, F., García-Durán, R., \& Martínez-González, A. (2013). Development and implementation of a biomedical informatics course for medical students: Challenges of a large-scale blended-learning program. Journal of the American Medical Informatics Association, 20(2), 381-387. doi:10.1136/amiajnl-2011-000796

Schön, D. A. (1983). The reflective practitioner: How professionals think in action. New York: Basic Books.

Stephens, M., \& Hennefer, D. (2013). Internationalising the nursing curriculum using a community of inquiry framework and blended learning. Nurse Education in Practice, 13(3), 170-175. doi:10.1016/j.nepr.2012.08.010

Stewart, A., Inglis, G., Jardine, L., Koorts, P., \& Davies, M. W. (2013). A randomised controlled trial of blended learning to improve the newborn examination skills of medical students. Archives of Disease in Childhood Fetal \& Neonatal Edition, 98(2), F141-4. doi:10.1136/archdischild-2011301252

Wald, H. S., Borkan, J. M., Taylor, J. S., Anthony, D., \& Reis, S. P. (2012). Fostering and evaluating reflective capacity in medical education: Developing the REFLECT rubric for assessing reflective writing. Academic Medicine, 87(1), 41-50. 


\section{Appendix A}

Exemplary Quotes Illustrating Each Element of Reflection and Level of Higher Order Thinking

\begin{tabular}{|c|c|c|c|}
\hline $\begin{array}{l}\text { Analysis } \\
\text { I }\end{array}$ & Code & $\begin{array}{l}\text { Element of } \\
\text { reflection }\end{array}$ & Exemplar quotes \\
\hline Breadth & CON & Content & $\begin{array}{l}\text { My topic for the Gardener's Tale was ability-ism. Initially when I got } \\
\text { this topic I thought it would be hard to write about. Then as I thought } \\
\text { about ability-ism, I realized it is a huge problem. This assignment made } \\
\text { me think about my blind friend and the problems he has faced because } \\
\text { of ability-ism. He is extremely smart and hard working, and the three } \\
\text { forms of ability-ism have influenced his life. So, how do we combat } \\
\text { these disparities....(560.8) } \\
\text { Previously I viewed my patient connections as a main strength, but I } \\
\text { feel like I can lose sight of establishing that in the program so far } \\
\text { because I'm trying to balance establishing a connection with getting } \\
\text { every question asked and recorded as well as thinking of every test that } \\
\text { needs to be done and what knowledge to incorporate...I can definitely } \\
\text { see how doctors and other health care providers lose sight of the patient } \\
\text { in the midst of the report/untangling the health issues and coming up } \\
\text { with an answer an plan. (516A.8) } \\
\text { One of the reasons I came to GWU was to diversify my patient } \\
\text { interaction and expose myself to a population that is very different than } \\
\text { my upbringing, rural America. I never thought of myself as biased, } \\
\text { racist, or closed minded, but I knew there were many healthcare groups } \\
\text { and disparities that I had never been exposed to. I was skeptical about } \\
\text { the Health Justice and Society course at the start of the semester } \\
\text { because I didn't think that you could teach someone to be unbiased or } \\
\text { non-judgmental. I thought it was more of a "I'm generally a nice, kind, } \\
\text { good person, and I'm not biased" thought process or not. I have learned } \\
\text { that this is not true at all...(507.8) }\end{array}$ \\
\hline & PROC & Process & $\begin{array}{l}\text { In preparing for the debates. I definitely grew in confidence as I found } \\
\text { my group to be very open to discussion and allowed each and every } \\
\text { participant to have a voice. Allowing me this opportunity and having } \\
\text { classmates not be critical or judgmental has been essential to my growth } \\
\text { in this area. I feel this is where I have had the most amount of growth, } \\
\text { because I can freely express and students are interested and have made } \\
\text { me feel that I have something worthwhile to say. Having the practice } \\
\text { and opportunity most certainly has aided the process of developing } \\
\text { verbal skills. I also have found that I have to process thoughts first and } \\
\text { either write them down or repeat them in my head before expressing } \\
\text { them (632.8) } \\
\text { To overcome the challenge, I had to continually remind myself that the } \\
\text { patient was in front of me and I should be more worried about the } \\
\text { conversation with her than getting everything on my checklist (516A.8) }\end{array}$ \\
\hline
\end{tabular}




\begin{tabular}{|c|c|c|}
\hline & & $\begin{array}{l}\text { The best way to not make judgments about other races or cultures is to } \\
\text { get to know people of that culture. I would hope that the majority of our } \\
\text { class has patient experience or just plain living experience with a mix of } \\
\text { ethnicities, but I'm sure many people have limited experience. How can } \\
\text { we use this class to broaden our experiences with other cultures and } \\
\text { races? Ideally it would be great to just volunteer at schools and nursing } \\
\text { homes...Even better, it would be great to have a little more diversity in } \\
\text { class! Then we could have discussions amongst ourselves and share } \\
\text { cultural experiences and ask each other questions. (650.8) } \\
\text { I haven't earned bad grades in quite some time... Now I am confronted } \\
\text { with the conundrum of putting forth a worthy effort and not getting the } \\
\text { expected results. I have had to step up my game much more than I } \\
\text { anticipated. I also have found that bouncing off issues with others has } \\
\text { helped me get to where I need to be. Before now, I was a lone wolf } \\
\text { when it came to studying and it worked. Having to make in-stride } \\
\text { corrections after the first round of tests was difficult, unanticipated, and } \\
\text { necessary. So I have learned to remain flexible with my study habits } \\
\text { and continue to adapt to this new intense program of study. (551.8) } \\
\text { I have learned that in order to breakdown personal bias you must be } \\
\text { actively reflecting and have a heightened sense of awareness about } \\
\text { where bias can creep into our daily life. I feel I am able to articulate my } \\
\text { opinion easily in a group discussion, but I have realized that I do not } \\
\text { readily carve out time for self-reflection. I find it helpful to have to } \\
\text { write or share my opinions in class or in a small group. Formulating an } \\
\text { opinion, and sharing it, seems to solidify the thought and makes me } \\
\text { more aware of my true opinion in relation to lowering disparities on a } \\
\text { personal, local, and day-to-day level. I also enjoy hearing other people’s } \\
\text { opinions so that I can take the pieces that fit my ideals to create a well- } \\
\text { rounded moral code of my own. (507.8) }\end{array}$ \\
\hline $\mathbf{M}$ & Premise & $\begin{array}{l}\text { I used to think that I was a relatively unbiased person, but I have a very } \\
\text { different view of myself now. I think I actually was pretty biased prior } \\
\text { to this program (mostly unconsciously) but now that I am aware of it I } \\
\text { am excited to challenge myself to overcome it...I am guilty of forming } \\
\text { preconceived notions for many of my classmates. (538.8) } \\
\text { I also found that I was judging other classmates as ignorant to religions } \\
\text { outside of theirs and insensitive to views of others. I need to not pass } \\
\text { judgment on them but accept that that is their opinion and they have a } \\
\text { right to their opinion. (612.8) } \\
\text { (Continued next page.) }\end{array}$ \\
\hline
\end{tabular}




\begin{tabular}{|c|c|c|c|}
\hline & & & $\begin{array}{l}\text { I mentioned that my most obvious subconscious bias as both a person } \\
\text { and a provider may be against extremely religious people, as I tend to } \\
\text { associate certain belief systems (ex: creationism, anti-vaccine) with a } \\
\text { lack of education rather than with faith. I stated that I just couldn't } \\
\text { understand how someone could believe in creationism, especially if } \\
\text { they're involved in the sciences. A classmate (and my personal best } \\
\text { friend) then perked up and stated that she, indeed, believed } \\
\text { simultaneously in creationism and evolution. The conversation } \\
\text { completely threw me off, because I was under the impression that those } \\
\text { two belief systems were mutually exclusive....I was very taken aback } \\
\text { by the conversation, but it made me realize my assumptions are often } \\
\text { completely incorrect. (515.8) } \\
\text { As I spend more time on intellectual reflection about } \\
\text { multiracial/multiethnic disparity, I began to realize that I have been } \\
\text { making wrong judgments on peoples' race/ethnicity with my limited } \\
\text { scope based on who could fit into what category and who could not.... } \\
\text { My knowledge of culture, ethnicity and racial identity had been } \\
\text { subconsciously internalized.... This course makes me be able to deeply } \\
\text { reflect on my ethnicity, which leads to admit the existence of other } \\
\text { cultures and to understand the differences with an open mind. (590.8) }\end{array}$ \\
\hline Depth & I & $\begin{array}{l}\text { Knowledge/ } \\
\text { Comprehension }\end{array}$ & $\begin{array}{l}\text { I thought it was a great experience to not only interact with the patient } \\
\text { but also to see some of my classmates interact with their patients. It was } \\
\text { really interesting to see how they approached the situations differently } \\
\text { than I would (606.8) } \\
\text { As brought up by Dr. X, regardless of one's religious affiliation, it is } \\
\text { important to be honest with your patients. Even if the provider does not } \\
\text { share the same beliefs as the patient, they can maintain trust with the } \\
\text { patient by being honest about their discomfort with taking part in } \\
\text { different religious practices. (564A.8) } \\
\text { I actually enjoyed the first debate because my group got to speak, but I } \\
\text { thought it was hard to stay focused on a debate that was presented twice } \\
\text { and that I didn't take a very active role. (513.8) } \\
\text { The worst part of the reading was the medical experimentation on } \\
\text { slaves. To think this happened as recently as } 150 \text { years ago is truly } \\
\text { shocking (588.1) } \\
\text { The story about the tattooed woman stood out in my mind because it } \\
\text { revealed conceptions that many people have about the type of person } \\
\text { someone might be who has tattoos. The shame she had endured in a } \\
\text { doctor's office is unacceptable (504.1) }\end{array}$ \\
\hline & & & (Continued next page) \\
\hline
\end{tabular}




\begin{tabular}{|c|c|c|}
\hline II & Analysis &  \\
\hline & & (Continued next page.) \\
\hline
\end{tabular}




\begin{tabular}{|c|c|c|}
\hline III & \begin{tabular}{|l} 
Synthesis/ \\
Evaluation
\end{tabular} & 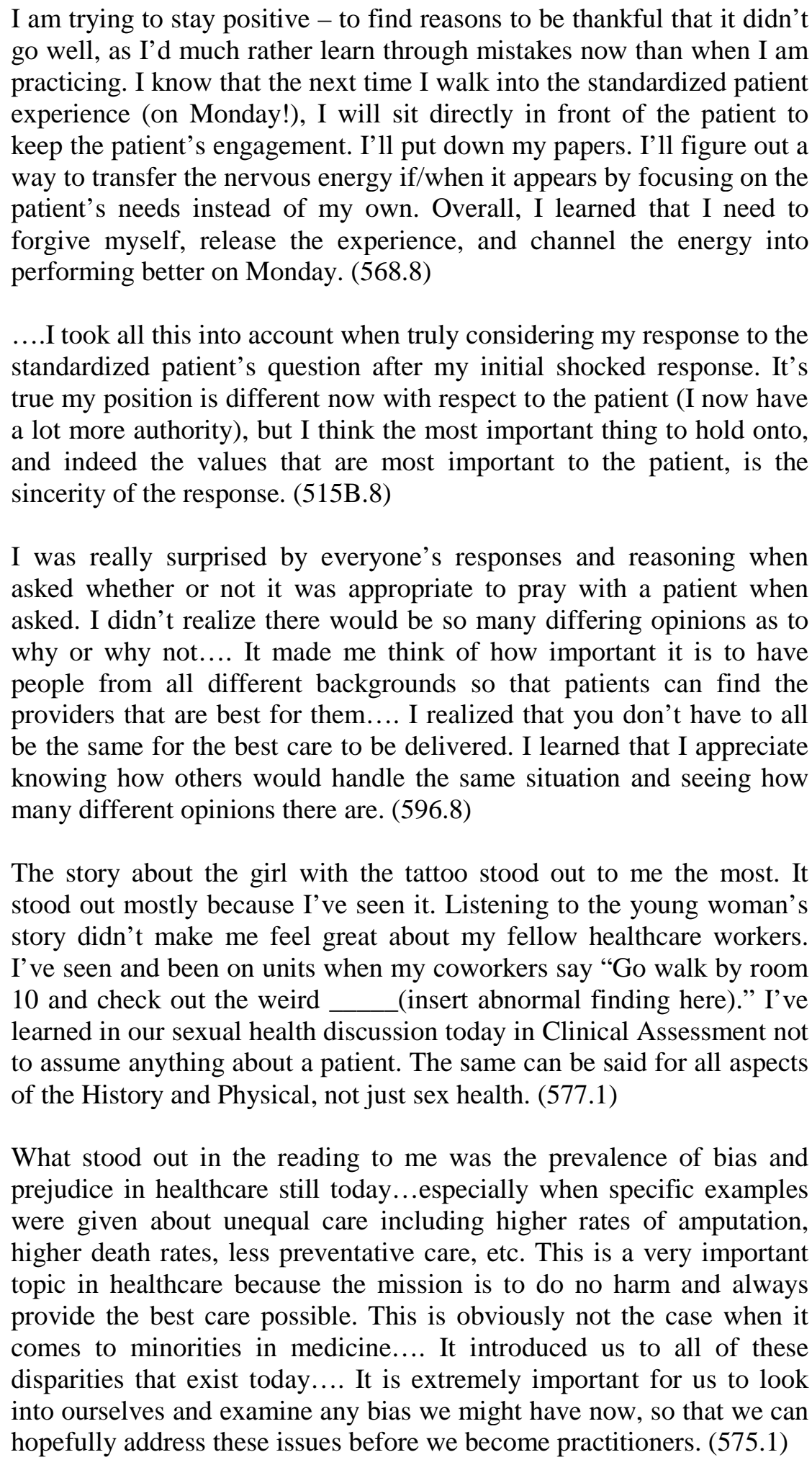 \\
\hline
\end{tabular}


